\title{
THE VITAL FORCES OF CHRISTIANITY AND ISLAM.-II
}

\author{
By The Rev. W. A. SHEDD, D.D.
}

The purpose of this paper is to reproduce the impression received during residence in a Moslem land from contact with Mohammedans in school work, religious discussion, social intercourse, and the various affairs of daily life. It is not an attempt to maintain a thesis, or to give an account of any phase of missionary work, or even to give the writer's final conclusions. He has sought to be frank and sympathetic in his relations with Mohammedans, among whom he feels it an honor to count not a few friends, and the effort will be to be candid in this attempted transcript of his impressions. In the nature of the case specific proofs cannot be cited for every statement. The range of observation is limited to one country and mainly to a single province, and to the smaller of the two great divisions of Islam, viz., to the Shi'a Mohammedans of the province of Azerbaijan in Persia. The paper is in part also an attempt to describe the attitude of Mohammedans towards their own religion and towards Christianity. This again, in the very nature of the case, is very difficult to do with fairness. In one respect there is perhaps danger of over-estimating the difficulty. The profoundness of the difference between the East and the West in their views of truth and attitude towards life has been a favorite subject of writers on Asiatic matters. No one can live in the East and attempt to enter into Eastern life without again and again being baffled by the different point of view from which Asiatics look at things ; but the con riction has grown in the writer's mind with the experience of passing years that the chasm is not impassable by any means. The theory that the race is divided into sections which are mutually inaccessible in intellectual and spiritual things is refuted by the whole trend of modern history. The social ideals of the West are penetrating the East and are laying hold of the masses in those lands. Under these conditions one has a right 
to expect that the religious ideas that have inspired Europe and America may be so presented in their inherent power that they may lay hold on the Mohammedan world.

What is the Moslem's attitude to his own religion? Which are the elements that hold him with living power, and which are those whose hold is weak or which he would throw off? Two preliminary remarks may be made. Obviously one must beware of universal statements. Mohammedans vary, as do Christians, in temperament and in education. A doctrine or a practice that holds one man with a powerful attraction may be repellent to another. In the second place, tendencies of thought and of theological development may be more significant than outspoken praise or blame. The former may be the unconscious expression of a deep need on the part of many, while the latter may represent the passing mood of a few. Usually the former is the summing up of a much larger experience than the latter.

Faith in one living God is certainly an element with living power. There are a good many sceptics in Persia but there are very few atheists. The language of everyday life is saturated with the acknowledgment of the living power of God. Most of the phrases, such as "If God will," "Praise be to God," "God forbid," are thoughtless expressions of habit and not acts of conscious faith; and yet custom in its origin is crystallized conviction, and if the conviction is lost the custom will pass into disuse. Besides, there are other evidences for the faith. There are very few suicides in Moslem lands, and that not because life is easy and men are contented. The reason is that the hereafter and the judgment are too vividly real for men to take liberties of that sort. The writer was talking not long since with a Moslem in a railway carriage in Russia and the conversation turned on recent political changes in Persia. The Moslem said that he believed that the Russian intervention was the means used by God to cast down the oppressors and to relieve the oppressed. It was not the expression of assumed piety but of a real conviction. Another Moslem was in the habit of saying that life's contraricties prove God's cxistence, meaning that the thwarting of our wills is the cvidence of a higher will. Islam assumes, and men 
assume in their daily lives, that this living God has a direct relation to men. He has sent a line of great prophets who have revealed His will for man in the form of law. He accepts worship and He hears prayer. Fatalism is not the ruling conception of the universe among Persian Shi'ite Moslems. The feeling of helplessness in the hands of an all-powerful Ruler is not absent, but it is softened both in theology and in popular feeling. What may be called the feeling that God is good-natured is very common. "God is gracious (karim)" is a very common expression, and the idea seems to be that $\mathrm{He}$ is not vindictive and will pass over little faults, especially in Mohammedans. The Nestorian Christian in an exactly similar way falls back on the expression, "God is merciful." In both instances the effect on morality is disastrous. The value of the faith in God's living power is limited by the defects in the character of God as conceived by Moslems, but the faith itself enters into life in innumerable ways.

The legalistic idea of merit plays a large part in life. This is the idea that certain acts, either those prescribed by the law or endorsed by religious custom, such as the fast and the various pilgrimages, or acts of mercy, are reckoned by God to the advantage of the doer. Theoretically the motive of the act enters into the reckoning of merit ; but practically this element has a very small part in it, so that one may say that in the popular idea the reward is not based on the ethical character of the act but is in large measure arbitrary. The thousands of pilgrims who every year go to the shrines and above all to Kerbala, the general observance of the Ramazan fast, the unintelligent reading of the Arabic Koran, the building of bridges, the indiscriminate giving of alms, and the support of religious mendicants are evidences of the power of this conception. No religious force works in more ways and more universally than this.

In Persia, faith in the Imâmat is another almost universal force. This implies that God not only reveals His will through the prophets but is in a more or less clearly defined way actually present in human life in some person, pre-eminently in the line of the Imâms, Ali and his descendants. This faith works out in various sects in manifold ways. It lay at the bases of the claims of Sayyid Ali Mohammed, the Bâb, and of his more famous successor, Baha Ullah. Around Lake Urumia in recent years a sect has gathered about the person of a religious teacher in Maragha, who claimed to be in some sense the resting-place of the divine presence. Such sects appear and disappear with each generation. Among the Ali Illahis, an ancient heretical 
sect and by far the most numerous of them all, the divine power is centered in the Pîrs, as their religious heads are called. The honor paid by the Persians to the Sayyids is connected with this belief, as they all claim descent from Ali. It covers and excuses a vast amount of rascality and rapacity.

Probably no Roman Catholic calls more instinctively on the Virgin and the saints for help than does a Shi'ite Moslem on the Imâms. The writer was once becalmed on the Lake of Urumia and the passengers, under the leadership of a lusty Sayyid, relieved the monotony of the hot and tiresome delay by praying for a wind. All in chorus would implore help from the great prophets and the Imâms, calling on each one in turn.

Closely allied to this belief is another religious force that is exceedingly strong among the people here. This is allegiance to a personal guide. It is the principle about which the darvish orders and the more irregular religious devotees cluster. The practices, such as the zikrs, in which the attempt is made to secure a mystical union with the divine through an emotional or sub-conscious bond, are carried on under the personal leadership of a murshid. The religion of the Kurds, who are Sunnis and not Shi'as, has for one of its main principles allegiance to their sheikhs, by whom they swear and to whom they do abject reverence. This allegiance is not tribal nor wholly hereditary, and to some extent it is voluntary, i.e., the individual chooses the religious leader whom he accepts. The authority descends more or less from father to son, but it is based originally on a reputation for ascetic holiness and devotion to religion. These sheikhs are, in many cases at least, descended from the Sayyids, or reputed descendants of the Prophet. The idea of personal authority underlies the ecclesiastical organization in Persian Islam, if it can properly be called an organization. There is no formal hierarchy, although the authority of the mujtahids, or accepted expounders of the law, is very great. The basis of the authority in practice, if not in theory, is democratic, and the measure of a mujtahid's authority is largely the amount and character of his popular following. Certain places, especially sacred shrines like Kerbala and Mashad and to a less extent cities of political importance, are recognized as sees of religious authority; but the choice of the occupant of any given see is exceedingly irregular and democratic. Acquaintance with a Persian will often reveal the fact that he is the disciple (murid) of some mujtahid, or it may be of a less authorized religious teacher, 
whom he regards as in a special sense his religious director and teacher. This element of personal influence is in accordance with the whole scheme of life, in which favor accorded on the basis of friendship and acquaintance plays a great part. The shopkeeper as a personal favor will change his price and the official will for your sake grant what is only your right. In civil life men will often put themselves under the protection of some powerful man, who has no legal claim on their allegiance, and he will accept them as his protéges. In religion this idea is found in the mediatorship of the prophets and holy men with Mohammed at their head, for whose sake the Ruler of the Universe grants favors and forgives sin.

It will be noted that the religious forces named do not all strictly belong to Islam. A full account would include a great mass of belief in magic, evil eye, charms, shrines, fortune-tellers, and such like, which cannot be described briefly and yet play a large part in the religious life of the people. For example, in the city where the writer lives one of the principal figures is a woman, a Jewish proselyte to Islam, who is something of a ventriloquist and evidently very shrewd. She claims to have a spirit at her service whom she calls Mohammed, who finds lost articles, gives information as to absent relatives, foretells the future, etc. She is consulted by all classes, including many Christians. Similarly Christian shrines are visited by Moslems to secure the favor of the patron saint. In a more intellectual way eclecticism is a living force. The tendency among many who are weary of the burdens and frivolities of traditional Islam is to fall back on a more or less vague theism, which is taken as the common foundation of the great religions. One is often told that the revelation is the same, though the mediums of revelation vary, that the actor is the same, though the mask and voice are changed. This has a basis in the claim of Mohammed that his message is the same in substance as that of Abraham and succeeding prophets. It is often joined with faith in some special religious leader, who claims to guide men anew in the one way of life.

\section{II}

Dissatisfaction with Islam may be traced along two lines. One is the expressed statements of individuals, and the other the attempt to supply deficiencies by importing and developing practices from without. Perhaps the second is the more significant. The most 
outspoken complaint is against the mullas and traditional practices favored by them. A cartoon in a paper published in Turkish by Moslems of Tiflis pictures the old and new eras. In the former a mulla is pulling a crowd of men along by a rope, while in the latter the rope is broken and the mulla is tumbling headlong. A Mohammedan recently made the statement that in certain regions to call a man an "akhand" (or preacher) is equivalent to reviling him. This is a revolt against abuses that are capable of reform without touching the essence of the faith. The nationalist revival in Persia leads occasionally to revolt against Islam as a foreign religion imposed on Persia by conquerors. An expression of this fecling in a newspaper was the cause of its suppression. There is complaint against the minute and vexatious requirements of the law, which expresses itself largely in the neglect of those requirements. There is a growing looseness in the keeping of the fast, though the breach is mainly in private and not in public. A zealous progressive suggested in his newspaper the abolition of the veil for women, with the result that he stayed a long time in prison. This complaint against the law strikes at one of the fundamentals of the religion ; for while the law may be drastically pruned without touching the Koran, its roots and some of its branches are in the holy book. Babism, or Bahaism, is largely an expression of this dissatisfaction, which it meets not by doing away with ritual law but by substituting a new law for the old. Any attempt to establish legislative government is bound to accentuate this conflict, for the idea of Islam is that government is not established to make law, but to enforce the already existing sacred law, which covers all departments of life.

An element of apparent strength in Islam is the brevity and simplicity of its creed and the way of salvation it offers. This is an apparent element of strength, because there is a great latitude of freedom, provided only the articles of faith are professed. The Mohammedanism of the schools is supplemented by a multitude of beliefs and practices, which are for the most part not Mohammedan in crigin ; and even the scholastic theology, through the medium or under cover of the traditions, has incorporated foreign elements. Almost any sect is tolerated in Persia, provided only that the creed, the fast, and a few other matters are respected so far as outward profession is concerned. The history of the incorporation of Sufism and the theory and practice of mysticism are to the point. These sentences are being written on the tenth of Muharram, the 
anniversary of the tragedy of Kerbala, in the mind of the Shi'ites the great martyrdom of history. From the city come the sounds of the mourning processions that pass along the streets, and they bring to the imagination the long lines of men and boys beating and cutting themselves in token of their participation in the grief of the tragedy. To-day is the great day, but for ten days private and public life has been subordinated to the same religious purpose. Sermons, poems, theatrical representations, and religious symbolism have all kept before the mind the day of Kerbala. This is the great religious demonstration of the year and also the national and patriotic celebration. Not only in its historical basis is it later than Mohammed but in its theological idea it is not Koranic. The bases on which it rests are the Imâmat and atonement through suffering, the abiding presence of the Divine in humanity and forgiveness based on propitiation. It is an attempt to meet the deep needs of the human heart which were ignored by the prophet, and to make of Islam a national faith in spite of the Arabs who murdered the descendants of the prophet. Strangely enough the fiercest partisans of the house of Ali and the most fanatical patriots are Turkish subjects of Persia, who nevertheless claim the heritage of Iran and not of Turan. The civilized and irreligious Persian may scoff at the ceremonies of Muharram, or grumblingly make public compliance to its demands, but it is prized by those who really seek after religion. Surely here is a deep dissatisfaction, which in order to meet its need has created a myth and founded a national cult.

\section{III}

The attempt may next be made to determine the attitude of the Mohammedan to Christianity, and to see how contact with it affects him. He is brought up to look on Christianity as a religion whose day is past, or possibly as one that answers well enough for the Christians but which is inferior to Islam. The question between Islam and Christianity was closed long ago by the prophet and sealed by the victories of the former. Islam was predicted, he believes, by Jesus Christ, and the failure to accept it is due partly to the fact that the true Injil was taken to heaven, and what remains is a book of distorted traditions. New light may arise for Islam by the coming of the Imâm Mahdî or by some working of the hidden Imâm, but not from Christianity. This assured position is shaken perhaps by the dis- 
covery that among some Christians there is a degree of truthfulness and unselfish service, such as he has not found in Islam; while further acquaintance may reveal to him that his ideas as to the beliefs of Christianity were largely erroneous, for example, that the Trinity is not three separate Persons, two of whom were of human origin, and that Christ is not regarded as the Son of God in the sense that he had supposed. On the other hand the superficial contact of a Mohammedan with Christians may have a repellent influence. Most of them meet him only in trade and their object is to get the best of him in a bargain. Others, it may be, are representatives of European powers, which according to his belief are set on exploiting if not destroying his nation. Western social habits are such as to be misunderstood and often to cause baseless scandal. To his mind many seem to be destitute of religion. A Persian who professes no religion and whose language is devoid of religious expressions is practically unknown, although his profession may be very different from his actual belief. The mutual recriminations of Christians of different sects have their share in strengthening his prejudices against all, though he has too often heard the tradition that there will be seventy-two or seventy-three sects in Islam to regard division as much of an argument against a religion. The above is not a complete statement of the difficulties that lie in the way of a Moslem giving to Christianity a fair hearing. The fear of the consequences of conversion, caused by the intolerance of Islam, is an important element. Ignorance, prejudice, contempt of subject races, misunderstanding, suspicion, fanatical pride, and the effect of the sins, errors, and lack of tact on the part of Christians help to pile up obstacles.

Other difficulties come up when he gives to Christianity a hearing. The doctrines of the Trinity and of the Deity of our Lord have been obstacles from the time of the Koran, and they are often made more difficult by the manner of their presentation. If he is persuaded to read the New Testament, he may find new difficulties in the form of the book, which is so unlike his idea of what a sacred book should be. He may be struck with the absence of law, which he has been taught is the object above all others of revelation. He has been taught that Christ was not really crucified, and so he is puzzled by the story of the crucifixion and the resurrection. The composite authorship of the book is also against his preconceived ideas. Possibly, too, the Christians seem to him in their informal references to the Bible and unconventional use of it not to show the reverence 
due to a divine book. His whole conception of religion is very different from the Christian conception. He has been taught-and even liberal Moslems seem to believe it - that in the Koran are to be found science, jurisprudence, politics, social ethics, and all else that enters into human life. The present leader of the Bahais, Abbas Effendi, states this idea of religion very definitely in relation to the Manifestation or Educator, whose guidance is to include by way of definite instruction every sphere of life. New Testament Christianity makes no such claim. It is a Gospel, centered in the life, teaching, death and resurrection of Jesus Christ. The miraculous element in the life is not a difficulty to the Moslem. Much in the teaching he cannot but admire, though the form is not what he expects. The-chief offence is the Cross. Recently I looked over some popular religious manuals published in the Transcaucasian (or Azerbaijan) Turkish by the more progressive Moslems. In them the story of Jesus is that founded on the suggestion of the Koran that He was rescued by God from death, some one else dying in His stead. The New Testament says that Christ died for sinners, willingly offering Himself. The Moslem says that a sinner died unwillingly in Christ's stead. For the glory of sacrifice the Moslem substitutes an escape wrought by God. This is done not out of perverseness, but from a desire to honor the Lord Jesus by saving Him from the shame of the Cross. Little wonder that the epistles do not appeal with power to Moslems, for they are saturated with faith in the death of Jesus. The conception of religion is different, and with this go different conceptions of salvation, of sin, and of forgiveness. The evangelical Christian and the Moslem move religiously on different planes.

Another difficulty lies in the sphere of character and ethical practice. The most deep-seated demoralization in Persian character is the result of the intolerance of Islam. Very possibly it goes back to the rule of the Zoroastrian clergy under the Sassanian kings, but at all events it was intensified by the Arab conquest. One may believe that the conception of an almighty and living God preached with the force of faith was a great factor in the conquest of Persia by Islam; but the sword was the most prominent factor and there must have been much insincere profession. As time passed and the irresistible speculativeness of the Persian mind produced variations of doctrine, some of them revolutionary in character, the insincerity became more widespread, particularly among the intellectuals. Finally Shi'ite Islam formally recognized the rightfulness of insincere pro19 
fession ; and this theory of ethics is accepted by every Persian sect, including the Bahais, and is practised by all. The greatest difficulty in presenting truth to a Persian is not the separation in intellectual conceptions and religious ideals but the lack of sincerity and frankness in all religious intercourse. Christianity must not and cannot meet men on any basis but that of truthfulness, and that common meetingplace is hard to secure in Persia. This insincerity may be covered by politeness, affability, and intellectual acuteness, but at bottom it is stubborn and ugly.

\section{IV}

The solvent that removes the prejudices of Moslems is love expressed in beneficent deeds and in unselfish character. Probably the greatest work that Christian missions have done in Mohammedan lands is to present in life and deed the fruits of Christianity. Hospitals, schools, relief of poverty, and integrity and honor in daily life have presented a new idea of service, religion, and manhood. This ideal differs from that of the saints of Islam. The position of woman in the Christian home and society has an attraction, especially for women. Many of them realize something of the evils caused by polygamy and divorce, and in general the relation of the sexes is so different in the two religions that the contrast cannot but be striking. More important than institutional Christianity is the influence of personal character in the social relations of life. Just what this has meant in Persia is shown in the biography of Dr. Cochran by Dr. Robert E. Speer. After his death Dr. Cochran's character was lauded by one of the most orthodox preachers in Urumia in a sermon in the mosque, and no one can tell how many prejudices were softened by that life of sincere service. The solvent that will remove the mass of misconception and mis-information is knowledge imparted in as non-controversial a way as possible. Much is being done to accomplish this indirectly, but there is need also for direct efforts in this direction. Not long since a mulla was for a few months a patient in a missionary hospital. He was a preacher of considerable reputation in his home city, and so he would influence the opinion of others as to Christianity. Before he left he asked for several copies of a little book that states in an uncontroversial way the doctrines of evangelical Christianity, in 
order that he might show his Moslem friends how erroneous were their ideas of the Christian religion.

The purity and nobility of the moral ideas set forth in the teachings of Jesus attracts some. A teacher of Moslem theology of some prominence once remarked to the writer that he believed that the teacher par excellence of morals and manhood is Jesus Christ. Some sayings, such as those about marriage, are criticized as impracticable, but nevertheless the attraction of the ideal is great. Another attractive element in the ethical character of Christianity is its adaptability to progress and freedom, because its ethics are not embodied in a legal code and because religion in its origins is not tied up with government. Argument along this line at least gains a respectful hearing. Some see that Church and State in Islam are inseparable, or separable only under non-Moslem rule, and that this is a great obstacle to social progress. The contrast on this point between Christ and Mohammed can be very helpful. Especially with the simple and more ignorant the gospel story of our Lord is attractive. The learned are apt to lose its beauty in the marvellous legends of Jesus found in the traditions. The gospel story takes the hearer into the heart of Christianity, and it brings up in a non-controversial way the fundamental differences between Christianity and Islam. As already pointed out, the death and resurrection of Christ have no place in Mohammedanism, and with this is connected the vital difference in the conception of salvation. So also anything that will lead Moslems to read the Scriptures is of great value. They at least will have many misconceptions corrected and may be led to deeper inquiry. The greatest attractive force is Christ Himself. No Moslem can speak of Him with anything but reverence, and we can let Him speak in His words in the gospels. The most uncompromising claims of Christianity are in those words. Just as far as we can base His claims on His own words, we make them strong. We must present $\mathrm{Him}$, as $\mathrm{He}$ offered Himself, as the Light and Truth of the world and as the Saviour and King of men.

\section{$\mathbf{V}$}

A topic of importance is the relation of the teachings of Islam to those of Christianity. The history of the rise and development of Islam would lead one to expect a close relation, and experience 
shows that the relation is complicated. A Mohammedan receives Christian truth into a mind filled with a large amount of belief. These previous beliefs can by no possibility be all expelled, even if it were desirable. Any attempt to dispossess a man of all his religious convictions in order that he may receive a totally new set is absurd. Furthermore, Christian faith is not a set of beliefs but the acceptance of a personal Saviour; and faith itself must be trusted to take possession of the heart and mind and to expel the alien affections and opinions. With a man born into a Christian environment a more or less definite set of Christian beliefs forms a part of that environment. He may himself conclude later that the beliefs are only partly Christian, or are only partially true to the facts of science or experience, and in all probability, consciously or unconsciously, the beliefs will change. Every intelligent Christian must be more or less aware of such a process in his experience. We must expect a similar process in the case of the Mohammedan who is drawn to Christ, and must not despise the day of small things. On the other hand, in order that a man should look to Christ as a Saviour there must be certain convictions, e.g., that he is himself in need of salvation, that there is a divine power that seeks to save, and that $\sin$ is not the inevitable condition of mankind. As one inquires after Christ, he finds that Christ Himself makes certain assertions regarding God and man, and makes certain claims regarding Himself. It is not necessary or possible that the sinner seeking a Saviour should accept definitely or understand fully all that is involved in those assertions and claims; but it is inconceivable, for example, that a man should accept Christ as Saviour and not say after Him, "Our Father who art in heaven."

The beliefs that seem thus to be inextricably related to the acceptance of salvation in Christ are not the same as those which revelation and Christian history have found it necessary to elaborate regarding the facts of spiritual life, and which may be essential in the subsequent Christian life. Even these latter cannot be ignored altogether in presenting the Christian faith to a Mohammedan. For example, the doctrine of the Trinity has been accepted by the Church and has become a part of its living experience. To the Mohammedan, as to most Christians, this doctrine stands in the forefront of Christianity as a presupposition, and not as a product of Christian life. The Christian missionary, although he may not believe that it is one of the primary doctrines for an inquirer, can- 
not ignore it or say that it belongs to esoteric Christianity, for there is no such distinction, and cannot be. The missionary must meet the issue and state the belief of Christians in the way best calculated to give the true impression, realizing meantime that the way of faith is the knowledge of God as Father, finding in Jesus Christ a divine Saviour, and experiencing in his life the working of the Holy Spirit. He can at least testify that this doctrine, which has been made a stumbling block, is to him the expression of the deepest experience of the soul and of the facts of redemption, and can strive to show how it makes the thought of God, the ineffable and absolute, nearer and richer in meaning, and intellectually more conceivable in His attributes and nature and in His relation to His creatures. Other doctrines that must be stated and defended are our belief as to Christ the Son, and our acceptance of the Holy Scriptures.

In brief, while the great end of missionary effort is not the substitution of one set of beliefs for another, but the presentation of Christ as Saviour, this implies a certain amount of doctrine, and in its working in life is inevitably associated with a body of more or less definite teaching. One must trust the "implanted word" to win the day for truth, once it comes into close quarters with error in the soul's warfare, and yet the openness and honesty of Christianity require that we state our beliefs and defend them.

It is obvious that the teachings received with Christianity, and those accompanying Mohammedanism, must in some measure lie side by side in the mind of any Moslem who receives in any degree Christian truth. How far will they come into conflict? How far is that conflict immediate and how far is it more remote and the result of the working out of belief? And how far will the beliefs previously accepted fit in with and strengthen those coming with Christian faith ? It is the conviction of the writer that there is no immediate casting off of one belief in God and the acceptance of another. Christians and Moslems are both believers in the Unity, the one God, creator and controller of all things. Probably no Mohammedan would seriously object to the reply in the Westminster Catechism to the question, "What is God ?", except perhaps to the word "Spirit," and then largely because of a confusion of terms. As the Christian revelation and experience fill the word "God" with richer meaning, the Mohammedan will find how utterly inadequate his conception was and alien elements will disappear. Our part is to strive to lead men to find the Father, or to find that Allah is Father, and that this 
name is greater than all those recounted on the beads of the pious. The type of Christian doctrine needed is not the high Calvinism that would limit His Fatherhood, nor is it the inchoate belief in a power working for righteousness. We have no right to lose the sturdiness of the Mohammedan's faith, though we may deplore its bareness of ethical content and the remoteness of God from the heart. The Persian idea of God is not so rigid as the Arab's, perhaps because his home is not in the wastes of the desert, and one has the right to use faith in God's immanence, though it may have degenerated into pantheism; his yearning for an incarnation, though it has led to subjugation to unworthy pretenders; and his revolt from absolute fatalism.

The second article in the creed of Islam is incompatible with Christian faith. It is not very material what view is taken of the character of Mohammed. The claims made by his Western apologists are mainly relative to his age and not absolute, as those of Christ; and if admitted go only a little way to substantiate what the Mohammedan means in confessing that Mohammed is the Prophet of God. He means that Mohammed is the last of the prophets and the greatest of all. Even those sects that believe in a later manifestation maintain Mohammed in the highest rank. And in popular Islam the glorification makes him superhuman. This claim carries with it the rejection of Christ except as a superseded prophet. It is not a question of a theory of the atonement or of the person of Christ, but of any atonement, any redemption, any incarnation that is in any way unique. The conflict of claims is immediate and cannot be stayed. A belief that is involved in the prophethood of Mohammed is that of revelation through human mediums and of sacred books that preserve the revelation. The common basis here is undeniable, but its value may easily be over-estimated. The Koran and the New Testament are so dissimilar in structure and purpose that it is useless to try to put the New Testament in the place in which the Mohammedan puts the Koran It is not enough, however, to show that the Christian conception of revelation is different. It must be shown to be richer and higher, and such it is.

It may be found in the end that the greatest preparatio evangelica in Mohammedan countries is in the religious life outside the lines of the Koran, and in the various semi-Mohammedan sects. The yearning after a mystical union with the Divine, the longing to see the divine image in some human life, the desire for a way of forgiveness opened 
by the self-sacrifice of divine love instead of the bare fiat of will, the vigils and prayers and aspirations of poets and philosophers, may be the most powerful Christward forces. It may be that many of these are echoes of Christian truth, for the witness to Christ has never been entirely wanting in the lands of Islam; and in any case they are from $\mathrm{Him}$, and $\mathrm{He}$ alone can guide these efforts to their goal and satisfy these longings.

Islam has one great lesson to teach us, the power of faith in a living God, not an abstraction, but one who rules the affairs of men. Another lesson is similar to this-the power of the appeal to personal authority. Nothing is more marvellous in Islam than the impress of the personality of the prophet on men of alien races and successive ages. As already pointed out, this force of personality is a striking feature in the religious life of Islam. It is the principal means used in the propagation of new sects and doctrines. For example, Bahais make very little use of the printed page, or of preaching in the formal sense in which the personality of the preacher is obscured in the conventionality of the address. The chief reliance is on the personal efforts of the "missionaries," who make the greatest use of informal social gatherings. The lesson is emphasis on the personal claims of our Lord, and faith in the power of personal influence exercised persistently through the channels of social intercourse, benevolent work, school life, or business. The missionary message of Islam has been in a sense a gospel, the definite proclamation of the personal relation of God to the individual. This is implied in the requirement that each Moslem confess his faith, and in the ritual prayer. But Islam in its workings is legalistic, and in developed Islam the law is the great institution of religion. The Pauline theology of free grace, and the great apostle's glory in the Gospel, are the message for Mohammedan legalism now as for Judaistic legalism in the first century. Life among Mohammedans leads one to rejoice in the conception of Christianity as the Gospel, the message of personal and social salvation. One rejoices in the freedom of Christianity from identification with any specific form of social or political organization, and in the inapproachable ideal of manhood revealed by Christ and being gradually learned and realized by His followers. One reads with new joy the great words of the apostles: "The law was given by Moses; grace and truth came by Jesus Christ," and "I am not ashamed of the Gospel: for it is the power of God unto salvation." 